\title{
A Case for Dehahuit's Village, Part II
}

Jim Tiller

Unknown

Follow this and additional works at: https://scholarworks.sfasu.edu/ita

Part of the American Material Culture Commons, Archaeological Anthropology Commons, Environmental Studies Commons, Other American Studies Commons, Other Arts and Humanities Commons, Other History of Art, Architecture, and Archaeology Commons, and the United States History Commons

Tell us how this article helped you.

This Article is brought to you for free and open access by the Center for Regional Heritage Research at SFA ScholarWorks. It has been accepted for inclusion in Index of Texas Archaeology: Open Access Gray Literature from the Lone Star State by an authorized editor of SFA ScholarWorks. For more information, please contact cdsscholarworks@sfasu.edu. 


\section{A Case for Dehahuit's Village, Part II}

Creative Commons License

(c) () () (9)

This work is licensed under a Creative Commons Attribution-NonCommercial 4.0 International License 


\title{
A CaSe for Dehahuit's Village, Part II
}

Jim Tiller

\begin{abstract}
In this, the second of a two part series on Dehahuit's village, we will use period materials to further establish a circumstantial case for the location of the village of this historic figure on Paw Paw Bayou in eastern Harrison County, Texas. In our discussion we will make use of selected distances and directions noted in the archival record and present a time and distance problem based on the journals of the Freeman and Custis expedition. We conclude with an analysis of Father José Puelles' 1807 map of Texas and William Darby's 1816 map of Louisiana.
\end{abstract}

\section{Introduction}

As discussed in A Case for Dehahuit's Village, Part I, ${ }^{1}$ Brooks' District Court statement and Sibley's comment regarding the Caddo living on a bayou named Sodo, when combined with the 1837 Caddo memorial, strongly suggest that the settlement of this historic figure has been mistakenly associated with the site on Jim's Bayou, referred to in recent years as Timber Hill.

In this the second and more speculative of the two articles in this series, the author will offer additional archival evidence and alternative interpretations of the record to buttress the circumstantial case for the location of Dehahuit's village on Paw Paw Bayou. We begin with a discussion of distances and directions from known points to the main or principal Caddo village (and thus the probable home of the great caddi) found in period records. We will next develop a time and distance problem related to Dehahuit's settlement as suggested in the journals of the 1806 Freeman-Custis expedition. We conclude with a consideration of the Sodo Lakes region Caddo village sites depicted on Father José Puelles' 1807 map of Texas and William Darby's 1816 map of Louisiana.

\section{Distance and Direction}

In the historical record, there are at least eight pieces of evidence (hereafter referred to as "items") related to distance and direction suggesting that the primary Caddo village during the early 1800s was located south of Caddo Lake (Figure 1). These would include the following

(1) In 1840, Jehiel Brooks, answering the memorial of Samuel Norris in the matter of the Grappe claim, made the following statement

The Indian south boundary as expressed in the treaty made by your respondent he believes cannot be questioned with any greater propriety. The Head Chief of the Caddo nation named Dehahuit or Dehahut resided at what has always been known by the name of "the Key Village" from the time of the first council ever held by this Government with that functionary in May 1805 to the time of his death in March 1833 which village is situated within a short distance of said Boundary and about ninety miles from the town of Natchitoches. ${ }^{2}$ 
(2) Indian Agent John Sibley, in his 1805 Historical Sketches, reported that the Yatasi tribe lived

on Bayou river (or Stony Creek) [the period name for today's Buffalo Bayou] which falls into Red river, western division, about fifty miles above Natchitoches. Their village is in a large prairie, about half way between the Caddoques and Natchitoches surrounded by a settlement of French families. The Spanish Government, at present, exercises jurisdiction over this settlement, where they keep a guard of a noncommissioned officer and eight soldiers. ${ }^{3}$

(3) In an 1809 report of the Barr and Davenport trading company of Nacogdoches, it was noted that

The old tribe of the Nacogdoches had its Rancheria about five leagues [13 miles] above the city of the same name ... On the Sabine, two leagues [5 miles] above the village of the Nacogdochitos was the pueblo of the Nadacos ... The Cadodachos were also on the east bank of the Sabine, some nineteen or twenty leagues [50-53 miles] above the pueblo of the Nadacos. ${ }^{4}$

(4) On entering the Red River above the Great Raft south of present-day Benton, Louisiana, Thomas Freeman (of the Freeman-Custis expedition) made the following journal entry

Beyond this Prairie [reference is to Caddo Prairie which extends north of Shreveport along the west side of the Red River] there is a large lake [Lake Sodo], on the west of which, and nearly 30 miles from Red River, lies the principal Village of the Caddos. ${ }^{5}$

(5) Once the Freeman-Custis expedition had arrived at the Coushatta village, Peter Custis made the following entry in his journal

The Caddoes reside about 50 miles from this according to some accounts \& not so far according to others, on a small Creek emptying into a lake which communicates with the River a little above the Raft. $^{6}$

(6) Trader Anthony Glass, writing from the Coushatta village at Cedar Bluff in 1808, observed that

[The Coushattas] are friendly with the Caddoes who own the Country \& who used to occupy the same spot; But now live about thirty Miles South West on the Lake. The Caddoes left the place on account of having lost many of their people by the small poxe, it being a custom to abandon a village where many have died. This place is nearly north latitude 32,50 , and distant from Nackitosh by the usual road about 120 miles in a rich beautiful place. ${ }^{7}$

(7) In his 1805 Historical Sketches, John Sibley wrote that the

Caddos Live about thirty five miles west of the main branch of Red river, on a bayou or creek, called, by them, Sodo, which is navigable for pirogues only, within about six miles of their village, and that only in the rainy season. They are distant from Natchitoches about 120 miles, the nearest route by land, and in nearly a northwest direction. ${ }^{8}$

(8) In 1840, 53 year old Joseph Valentin testified that over the years he had frequently accompanied the Caddo during their winter hunts and that when not hunting, the Caddo

resided for the most part at their villages at the head [author's emphasis] of Cos Lake ${ }^{9}$ 


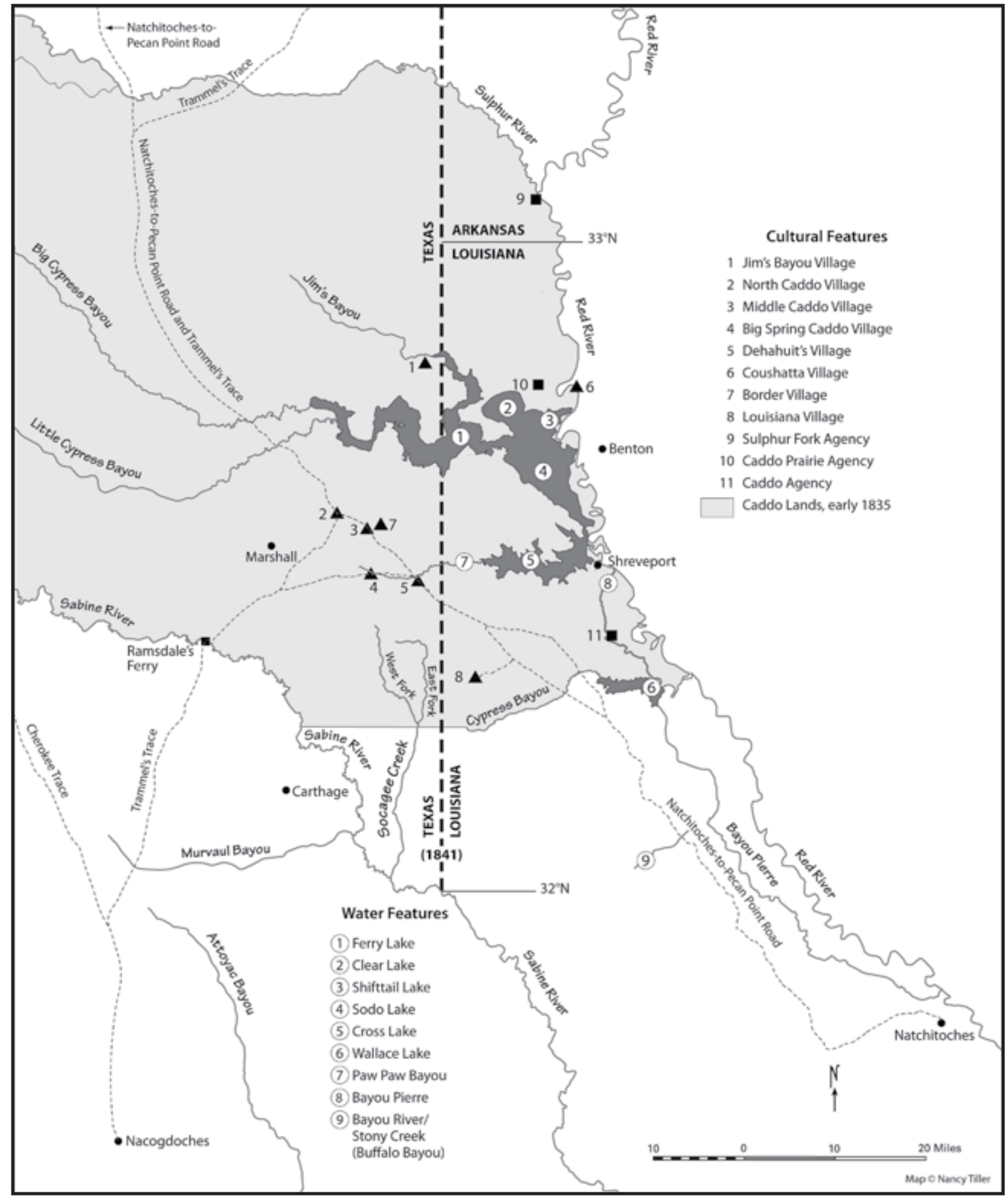

Figure 1. The Sodo Lakes Region, 1838. Marshall, Carthage and Benton are provided as reference points. 
As discussed at some length in Part I of this series, the most significant evidence related to distance is the statement of Brooks who noted that the village of Dehahuit was located near the south boundary of the Caddo lands and some 90 miles from Natchitoches (item 1). ${ }^{10}$ When combined with Sibley's 1805 statement regarding the location of the Caddo relative to the Yatasi tribe and the town of Natchitoches (item 2), the primary Caddo village appears to have been situated approximately 90 to 100 miles above Natchitoches at a point on what would later be known as the Natchitoches-to-Pecan Point Road. As calculated on later American survey plats (in 1805, what would in time become known as the Natchitoches-to-Pecan Point Road only extended from Natchitoches to the Bayou Pierre settlements), Dehahuit's village was located south of Ferry Lake approximately 87 miles from Natchitoches. From a slightly different perspective, the report of Barr and Davenport (item 3) places the Caddo approximately 70 miles (27 leagues) above Nacogdoches, possibly in the general area of Cross Lake. Valentin, in noting the Caddo lived in villages at the head of Cross Lake when not out of the area, certainly suggests that the region west of Cross Lake was the center of the Caddo culture in the Sodo Lakes region, and, by inference, makes it very likely that one of these Cross Lake villages was the home of Dehahuit. It is difficult to see how proponents of the Jim's Bayou site as the home village of Dehahuit can square these statements with a location north of the lakes (Figure 2). ${ }^{11}$

In the journals of the Freeman-Custis expedition (as interpreted by Flores), the party, after a journey east around the Great Raft, re-entered the Red River below Benton, Louisiana near Willow Chute (item 4). ${ }^{12}$ The 30-mile distance referenced by Freeman was almost surely measured in a straight line from a point near Willow Chute to the principal Caddo village. Considering the wording of the journal entry ("beyond this Prairie ... large lake") it does not appear Freeman was suggesting a land route around Shifttail and Clear Lakes and the Jim's Bayou arm of Ferry Lake to the primary Caddo village. Clearly, the implication is that from expedition's river location the principal Caddo village was situated beyond Caddo Prairie and to the west of a large lake (probably Lake Sodo). If the reference was to the Jim's Bayou site, this was indeed an odd way to describe the location. At the very least one would have expected the word "beyond" to have been amended by Freeman to read "northwest of."

Regardless of whether one considers the distance to be the 30 miles of Freeman (item 4) or 50 miles (or a little less) of Custis (item 5), 30 miles according to Glass (item 6) - and observe that both Custis and Glass are providing distances as measured from the same point, the Coushatta village - or the 35 miles as estimated by Sibley (item 7), it appears the village being referenced was not the Jim's Bayou site, it being only 17 straightline miles from the Coushatta village. In addition, note the direction provided by Glass to the Caddo villages - to the southwest. In fact, the Jim's Bayou site lies slightly to the north of a point due west of the Coushatta village. While items 2-6 would suggest a location to the south of the Sodo Lakes complex, Brooks' comments in item 1 and Valentin's in item 8 leave no doubt that the primary Caddo village and, thus the probable home of Dehahuit, lay a considerable distance south of Ferry Lake. 


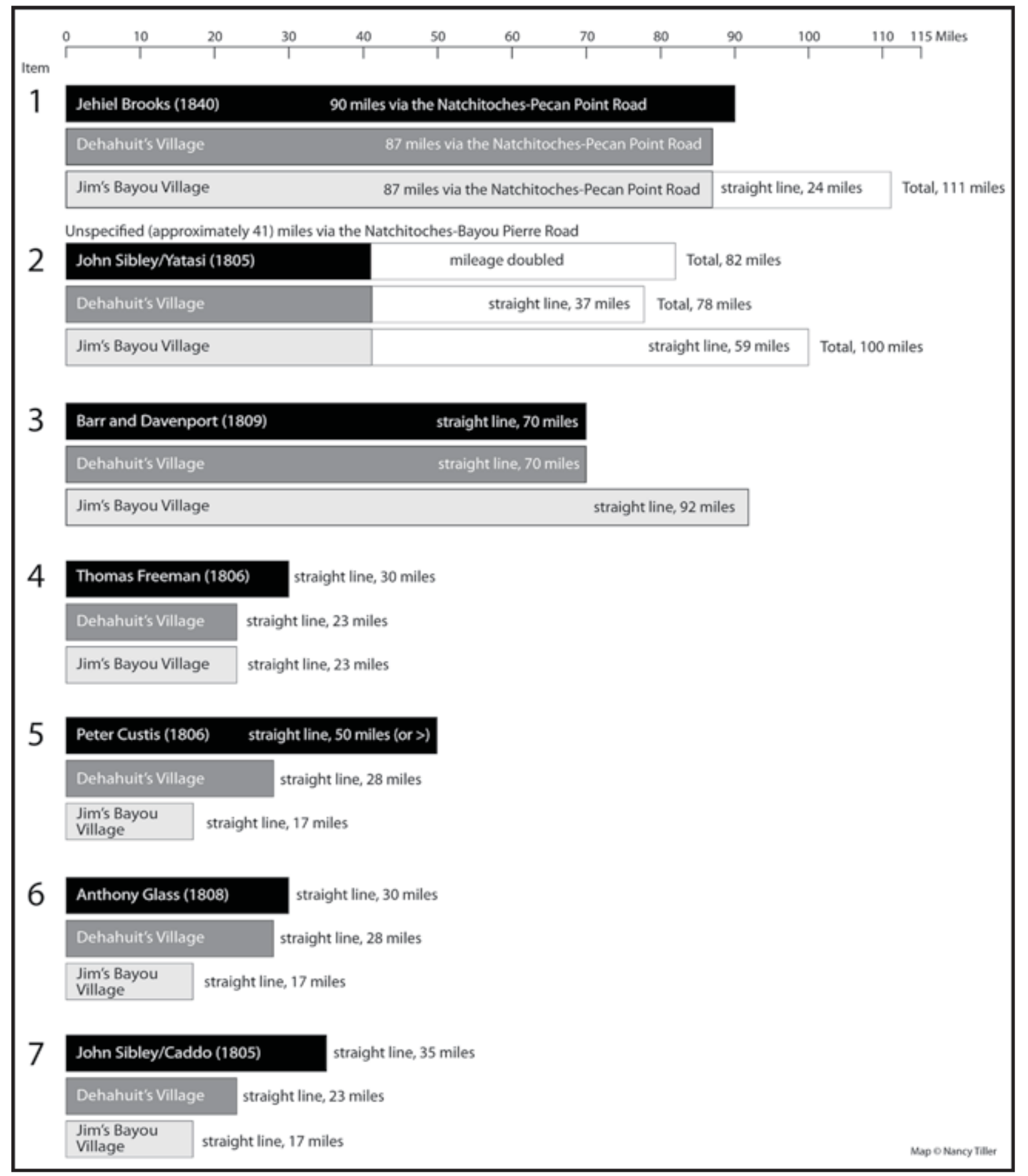

Figure 2. A Comparison of Distances Between Selected Locations ${ }^{39}$ 
Interestingly both Glass (item 6) and Sibley (item 7) reference a 120 mile distance from Natchitoches - Glass noting this as the distance to the Coushatta village via the "usual road," and Sibley's 120 mile estimate to the Caddo villages as "the nearest route by land." From his journal, there is little question the route travelled by Glass lay up the east side of Red River. This route probably very closely followed the road through “Tulin's Vaucherie" and around Lakes Bistineau and Bodcau to the Coushatta village depicted on William Darby's 1816 map of Louisiana (Figure 3). As this was the "usual road" between Natchitoches and the Coushatta village during the early 1800s (and it seems reasonable to assume that Sibley would have been well aware of the approximate 120 mile distance between these two points), and since we know the Jim's Bayou site is found some 17 straightline miles west of the Coushatta village, it is doubtful that Sibley was describing the Jim's Bayou site (nor Sodo Bayou) in his Historical Sketches as being 120 miles from Natchitoches as measured up the east side of the Red River along the "usual road."

Nor does it seem likely that Sibley's 120 mile distance between Natchitoches and the Caddo villages related to a route up the west side of Red River. While a distance of 120 miles via the Natchitoches-to-Pecan Point Road and then around Caddo Lake would in fact put one in the general area of the Jim's Bayou village site, what is often overlooked in this 1805 statement is that Sibley indicated the distance was "the nearest route by land." In 1805, not only was there no Natchitoches-to-Pecan Point Road, it is doubtful (see comments of William Darby below in the section on Darby's Caddo village) that a commonly accepted route aside from hunting/trading paths to the northwest even existed on the west side of the Red River above the Bayou Pierre settlements.

Is it not possible that Sibley's route followed, at least in part, the route travelled by Glass and depicted by Darby? Note on Darby's map the second fork in the road north of Toulin's vaucherie. What reason could possibly justify the presence of a ferry across Lake Bistineau at the point? The ferry crossing is not at the lake's narrowest point assuming one is intent on continuing northward along the road indicated. Even more important, for what reason does this ferry crossing exist in this sparsely populated area if one is only to rejoin the original road to the north? The distance saved by such a route would have been minimal and likely would not have justified the expense of the ferry. It seems clear to the author that while Darby did not indicate the presence of another road/path west of Lake Bistineau, one surely must have existed. That road/path in all probability extended west from the ferry crossing to the Raft, thence to Cross Bayou (hence a possible origin of the name of the bayou and lake), then west along the old Indian trail to the Caddo villages. In later years this route west out of Shreveport (US Highway 80) would follow the watershed divide which separates streams flowing north into Cross Lake from those flowing south into Boggy Bayou/Wallace Lake. A route such as described would have fallen within Sibley's 120 mile "the nearest route by land" estimate.

Of course, one cannot be certain Sibley was in fact referencing a route up the east side of the Red River; however, considering Darby's comments regarding how little was known of the region north of the Bayou Pierre settlements were made several years after the writings of Sibley and Glass, it is not unreasonable to suggest that Sibley was in fact alluding to the most commonly used route into Indian country south of the Sodo Lakes complex in the years immediately following the 1803 Louisiana Purchase. 


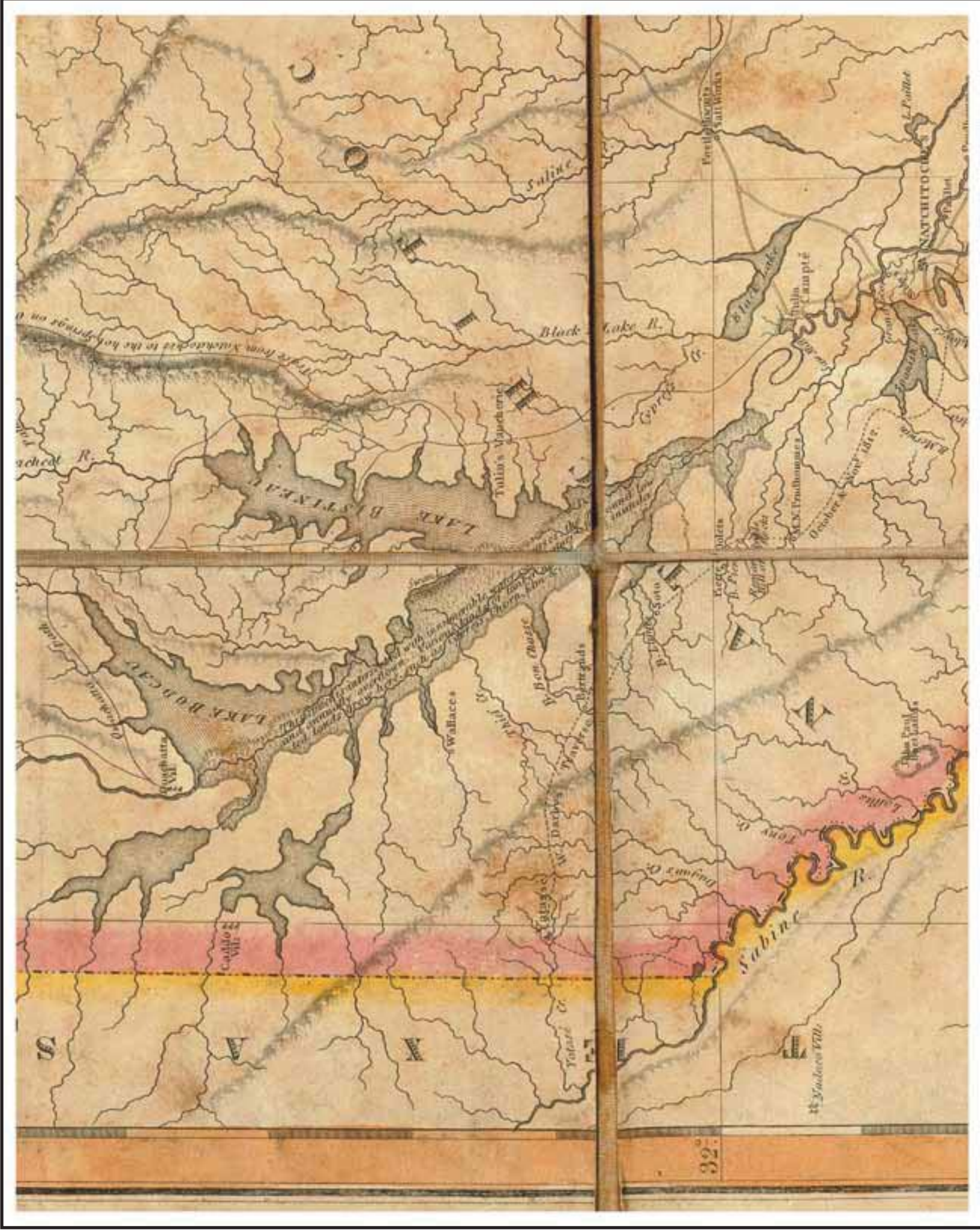

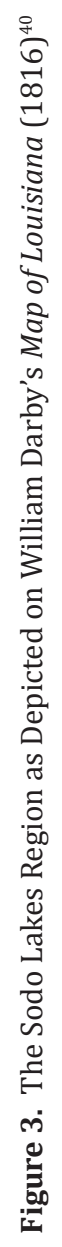




\section{Time and Distance}

Interestingly, we have in the journals of Freeman and Custis a number of references related to time and distance (Figure 4). Consider the following

(9) As the expedition party began to ascend the river (they had only gone about one mile), they were met by a messenger. He brought them word that

About 300 Spanish Dragoons, with 4 or 500 Horses and Mules were encamped a few miles back of the Caddo Village ... After delivering this message, the Indian [the messenger originally sent by the Caddo Chief, Dehahuit] said the Caddo Chief requested Mr. Touline [aka François Grappe] to go to him immediately on our arrival at the Coashutta Village, as he wished very much to see him; but if M. Touline could not go to the Caddo Village, the Chief would meet him at the Coashutta's, and expected the Spanish officer would wish to accompany him. ${ }^{13}$

(10) The messenger was then

dispatched immediately [on June 24th], with a request that the Caddo Chief should meet M. Touline alone, at the Coashutta Village. ${ }^{14}$

(11) After a period of several days at the Coushatta village

The Caddo Chief not arriving on the 30th as was expected, Mr. Touline dispatched a favorite Indian, the same one who had piloted the party through the swamp, to the Caddo Nation to learn the cause of his delay; with instructions to return almost immediately. The next morning a runner arrived at the camp, with intelligence that the Chief and 40 of his young men and warriors were on their way from the Caddo Village, and would arrive about noon. At the time expected, they made their appearance on the south side of the river, about a quarter of a mile above the camp..$^{15}$

The expedition re-entered the Red River on June 24. At that point, they were approximately 19 miles from the Coushatta village. As they began to move upstream, they had gone approximately one mile when they were met by a messenger from Dehahuit who informed them of the presence of Spanish troops near his village and delivered the request for Touline to come to him once the expedition had arrived at the Coushatta village (item 9). Touline declined and instead, as suggested by the chief, told the messenger he would meet him at the Coushatta village (item 10).

It was anticipated that Dehahuit would come to the Coushatta village on the 30th, but he did not arrive as expected (item 11). A runner (Touline's "favorite Indian") was sent to determine the cause of the delay. The next morning (July 1), a runner arrived at the Coushatta village with the message that Dehahuit and his party would arrive about noon. It is not clear if this runner was the same one dispatched by Touline the day before - he possibly having met the Caddo party in route and returned to the Coushatta village with word of Dehahuit's location, or if this was a runner sent ahead by the Caddo chief to alert the Coushatta and members of the expedition of his imminent arrival. The fact the journal entry notes that "a" runner was dispatched on the 30th and "a," and not "the" runner came back/returned on July 1 suggests that the runners were not the same individual. 


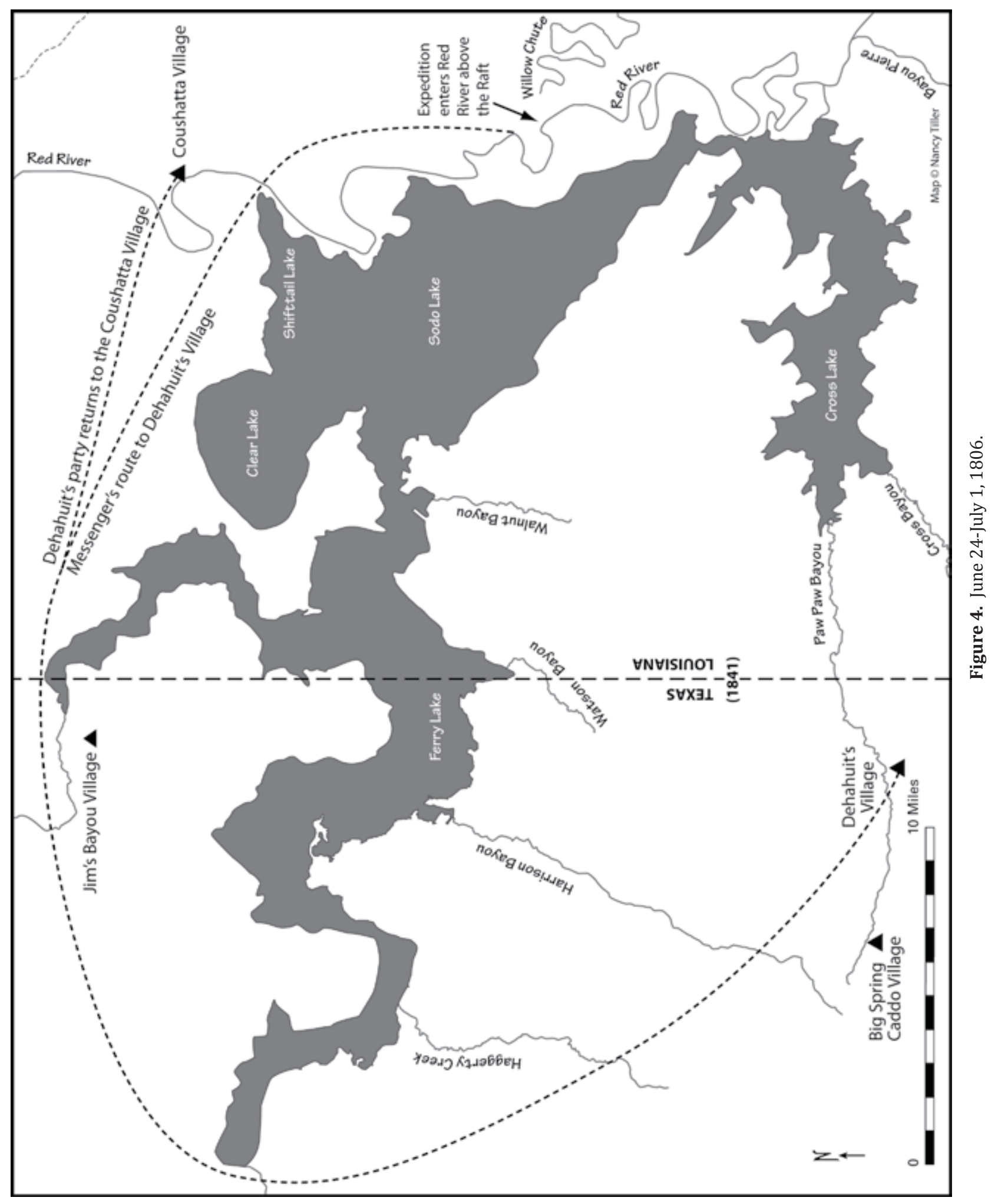


Notice seven days elapsed between when the initial messenger was sent to the Caddo chief and the arrival of Dehahuit at the Coushatta village. He was expected on the 30th - six days after the messenger was dispatched from a location near Willow Chute. Why such a timeframe? The answer is suggested in the expedition journals.

The original messenger which met the expedition party at Willow Chute was ordered by the Caddo chief to return to him with word of whether or not Touline would be coming to the Caddo village. Touline declined to go and this information was sent back to Dehahuit with the return messenger on June 24th (item 10). Since Touline would not come to the Caddo village, Dehahuit (who was asked not to bring a Spanish officer - he was to come "alone") came to the Coushatta village. Central to our discussion of the location of Dehahuit's village is the probable route taken by the messenger who returned to the Caddo village from Willow Chute, and, upon having received the message, the path most likely taken by Dehahuit to the Coushatta village.

There are no maps available that show an early 1800 road network in the area under discussion, thus the author proposes two of the most likely routes that could have been used by the Indian messenger as he moved from the expedition on the Red River to Dehahuit's village. The most probable path would have involved moving north then west around the western end of the Sodo Lakes complex.

The second route, improbable as it may initially appear, could have involved a journey "across" Sodo Lake. Having been first formed in the spring of $1800,{ }^{16}$ it is very likely that by 1806 the lakes had not taken on the general configuration they exhibited in the 1838 American surveys (see Figure 1). Certainly there are many period maps that suggest the size and shape of the lakes complex varied widely depending upon the year and season viewed. Because the lakes took a number of years to stabilize, it seems very likely that in the years immediately following their creation shallower portions of the lakes dried up in the sense that portions of a lake disappeared leaving only the central stream (Big Cypress-Twelvemile Bayou or Paw Paw-Cross Bayou). ${ }^{17}$ No longer an impassible barrier, local inhabitants took advantage of the situation and returned to the use of paths that had existed prior to the creation of the lakes. One such route doubtless would have connected the Caddo villages south of Sodo and Cross Lakes with the Caddo Prairie-Coushatta village region north of present-day Shreveport.

Based on the journal entry of Freeman, it is doubtful any use was made of an across-Sodo Lake route in the summer of 1806. Freeman tells us that guide and interpreter Talapoon had been previously sent from Natchitoches around the Raft with a request for the Caddo chief to meet the expedition at the Coushatta village. ${ }^{18}$ Upon receiving this message, Dehahuit sent a return messenger (doubtless accompanied by Talapoon) via the Coushatta village to Touline (item 9), who Custis described as "a worthy and respectable old French gentleman, whose friendship for the Americans induced him to accompany us this far."19 It seems reasonable to suggest that Talapoon, in going "round from Natchitoches," had in fact gone up the west side of the Red River directly to the Caddo village At this point, he joined the Indian messenger who was to deliver Dehahuit's message to Touline. Had the more direct Sodo Lake option been open to them, it seems likely that these two (probably) physically vigorous individuals would have taken it rather than the much longer route around the western end of the lakes complex. In fact, they did not. Freeman tells us that the expedition met the two as they were coming downstream in a canoe, presumably from the Coushatta village. ${ }^{20}$ Too, note that Dehahuit in his message requested Touline come to him (at his village) immediately upon his [Touline's] arrival at the Coushatta village (item 9). Had a Sodo Lake-Twelvemile Bayou route been open, it seems very unlikely that Dehahuit would have requested the highly respected, old and presumably less than agile Touline to go out of his way to the Coushatta settlement, then around the lakes to his village. It is the belief of the author, based on the journals of Freeman and Custis, that in the summer of 1806 the lake waters were of sufficient height to make a journey directly from the Red River

\section{6 - Volume 21, 2011}


to the Caddo village area south of present-day Caddo Lake too difficult for even the most physically vigorous. ${ }^{21}$

The author estimates that a trip on foot from the Willow Chute area north and west around the Sodo Lakes complex to the proposed Dehahuit's village area at the western end of Cross Lake would have been approximately 55 to 60 miles (a hard two days - with the messenger assumed to be on foot as no mention is made of horses in the expedition journals. The return trip by horseback from Dehahuit's village to the Coushatta settlement would have been approximately 50 miles (a long one day or possibly a day and a half journey). Freeman tells us that the Caddo chief was not expected to arrive at the Coushatta village until June 30 (item 10) - a full six days after the Indian messenger left the expedition on Red River to return to Dehahuit's village. It is the belief of the author that the six day period was required to provide time for the messenger to leave the expedition, return to the Caddo village, inform the chief of Touline's decision, have the chief prepare for the journey, and then make the trip north and then west around the lakes to the Coushatta village. Had Dehahuit lived at Jim's Bayou, some 25 miles from the point the Indian messenger encountered the expedition, and less than 20 miles from the Coushatta village, it seems doubtful, especially considering the expressed desire of Dehahuit to seek the advice of Touline as soon as possible, that he would have spent three or four days (after receiving Touline's answer) getting prepared for a half-day journey.

It should also be noted that there is absolutely no basis in the expedition texts for believing that the chief's party, which arrived by noon on July 1 (six or seven days after the messenger left the expedition at Willow Chute), departed the village on Jim's Bayou on the morning of that same day. ${ }^{22}$ In fact, they had almost surely been on the road for at least one full day and possibly a part of a second day.

Finally, it is important to consider item 12 . The chief, Dehahuit

said he was sorry his village was so far ... He hoped we would excuse him for taking with him so many men to trouble us, as most of them were young men who had never been so far as the Post and had a great curiosity to see their new friends. ${ }^{23}$

This statement suggests to the author, especially in view of the totality of the material discussed in this series of articles, that the village of the Caddo chief was a considerable distance from the Coushatta village - so far in fact that many of the 40 young Caddo warriors who accompanied him had never been to the village. It seems improbable that young Caddo warriors would not, at some point, have made the trip to the Red River Coushatta settlement had their village been located on Jim's Bayou, less than 20 miles distant (maybe a half-day's ride - there and back in one long day). On the other hand, it seems more than reasonable to suggest that young warriors would have been less inclined to travel around the western end of Ferry Lake to the Coushatta village, a one-way distance of approximately 50 miles, and a journey that would have required, at a minimum, an overnight stay.

The author believes the material presented in the journals of Freeman and Custis and discussed above provide additional circumstantial evidence that the village of Dehahuit was in fact located south of Ferry Lake and at a considerable distance from the Coushatta village. 


\section{Sodo Lakes Caddo Villages and the Maps of Father José Puelles and William Darby}

Any discussion involving the use of early 1800s-era maps to locate one point relative to another requires careful analysis; and this is especially true when the discussion relates to maps of northwestern Louisiana and adjacent eastern Texas. Few persons possessing the necessary equipment for taking even semiaccurate geographical readings had visited the region prior to the 1820 s. As a result, no cartographer really had a firm grasp of the subtleties of the physical landscape. In fact, many of the maps of the period simply, rightly or wrongly, recycled earlier findings. An immensely complicating factor all cartographers had to contend with was the presence of the Great Raft of the Red River. The Raft, the river and its floodplain were comprised of an ever-changing maze of bayous, lakes, wetlands and woodlands - and as the Raft slowly made its way upstream, what one year was a dry prairie could the next year be a lake or vast swamp. Cartographers typically depicted the Raft on period maps as simple interconnected streams with little effort being given to precisely locating specific waterbodies within the larger region.

The Sodo Lakes complex offers an especially interesting situation. Largely situated above the Raft, the region presented travelers with a series of lakes that changed their size and shape each year depending upon the configuration of the terrain and amount of water available from the Red River and its tributary streams. Although first formed in the spring of 1800, it probably took a number of years for the lakes to assume some semblance of permanence. While there is no question the lakes were present on the landscape after 1800, they were doubtless subject to wide fluctuations in both size and shape, and they rarely appear on maps of the region prior to the $1820 \mathrm{~s} .{ }^{24}$ As late as 1834 , Burr's map of the area depicted only a single lake in the region, that one lying to the east of the Red River. ${ }^{25}$ In the paragraphs to follow, we will examine the relative location of the Sodo Lakes area Caddo villages found on Father José Puelles' 1807 map of Texas and William Darby's 1816 map of Louisiana.

\section{The Caddo Village on the 1807 Map of Father José Puelles}

As noted previously, in 1806 President Thomas Jefferson sent Thomas Freeman and Peter Custis up the Red River to explore the southwestern boundary area of the recently acquired Louisiana Purchase. As Spain claimed the lands bordering the river in its middle and upper course, troops were dispatched to intercept the American party once it left Natchitoches. In time, Spanish soldiers would make their way to a point just west of the Caddo village described in the Freeman-Custis journals. In July 1806, after choosing not to attempt to stop the Americans in the area of the Coushatta village, Spanish forces left their position behind Dehahuit's settlement and moved northwest around the Sodo Lake complex, then north to the Red River where they intercepted and turned back the expedition near Spanish Bluff.

Interestingly, the route taken by the Spanish from Nacogdoches to Spanish Bluff is traced on Father Puelles 1807 Mapa Geographica de las Provincias Septentrionales de esta Nueva Espana. ${ }^{26}$ Early nineteenthcentury maps of Texas produced by this cartographer-priest, who typically made extensive use of information gathered from soldiers and others who actually visited the areas mapped, are widely recognized both for their detail and accuracy. Many, such as Stephen F. Austin who prepared maps of Texas during the early 1820s, were heavily influenced by the work of Puelles. ${ }^{27}$ In the paragraphs to follow, we will examine that portion of the Puelles map depicting northeast Texas and adjacent Louisiana, giving special attention to the relative location of the Caddo village.

While it is not possible to precisely establish the latitude of the Caddo village on Puelles' map, Father José Pichardo in his 1812 Treatise on the Limits of Louisiana and Texas indicated that the village was located on the Puelles map at $32^{\circ} 26^{\prime}{ }^{28}$ Pichardo, who was tasked with providing the Spanish government with 
arguments relative to Spanish and American claims along their common border, had wide access to Spanish archival materials, and doubtless the village grid point was taken from these files. Jackson tells us that due to sickness then raging through Nacogdoches, Puelles was "kept out of the saddle" and thus did not accompany Francisco Viana to the Spanish encampment behind the Caddo village. Jackson suggests that Puelles most likely obtained the coordinate of Dehahuit's village from Viana, although he notes that Elizabeth A.H. John speculates that rather than Puelles, the young cartographer John Peter Walker, a skilled surveyor and an individual very familiar with taking astronomical readings, may have actually accompanied the Spanish troops to the Caddo settlement and was thus the source of the grid location. ${ }^{29}$ While the exact source for the latitudinal coordinate of the Caddo village is unknown, it seems likely that it was probably provided to Puelles from the papers of either Viana or Walker, both certainly capable of providing a relatively accurate latitudinal reading. The PichardoPuelles-Walker grid point of $32^{\circ} 26^{\prime} \mathrm{N}$ would place the Caddo village depicted on Puelles map only three miles south of the modern-day coordinate of Dehahuit's village as proposed $\left(32^{\circ} 29^{\prime} \mathrm{N}\right)$.

Note on Figure 5 the path over which the Spanish forces moved once they left Nacogdoches. It is the contention of the author that the initial leg of the route taken out of Nacogdoches closely coincided with that of modern-day US Highway 59. The early 1800s Nadaco village on the Puelles map probably lay in very close proximity to present day Mt. Enterprise. The large hill from which the community takes its name was doubtless a major landmark to period travelers. In fact, both the Cherokee Trace and Trammel's Trace of later years converged on the northwest side of this prominence. Upon reaching the hill, the Spanish troops veered northeast passing just north of the headwaters of Attoyac Bayou. Closely following the route of modern-day State Highway 315, they likely passed near modern-day Carthage then along US Highway 79 to the general area of De Berry where they turned north. Moving along the west side of the west fork of Socagee Creek, and taking advantage of the region's many large springs, the soldiers ultimately took up a position some six miles west of Dehahuit's village on Paw Paw Bayou at a location or near what would later be known as the site of the Big Spring Caddo village (see again item 9).

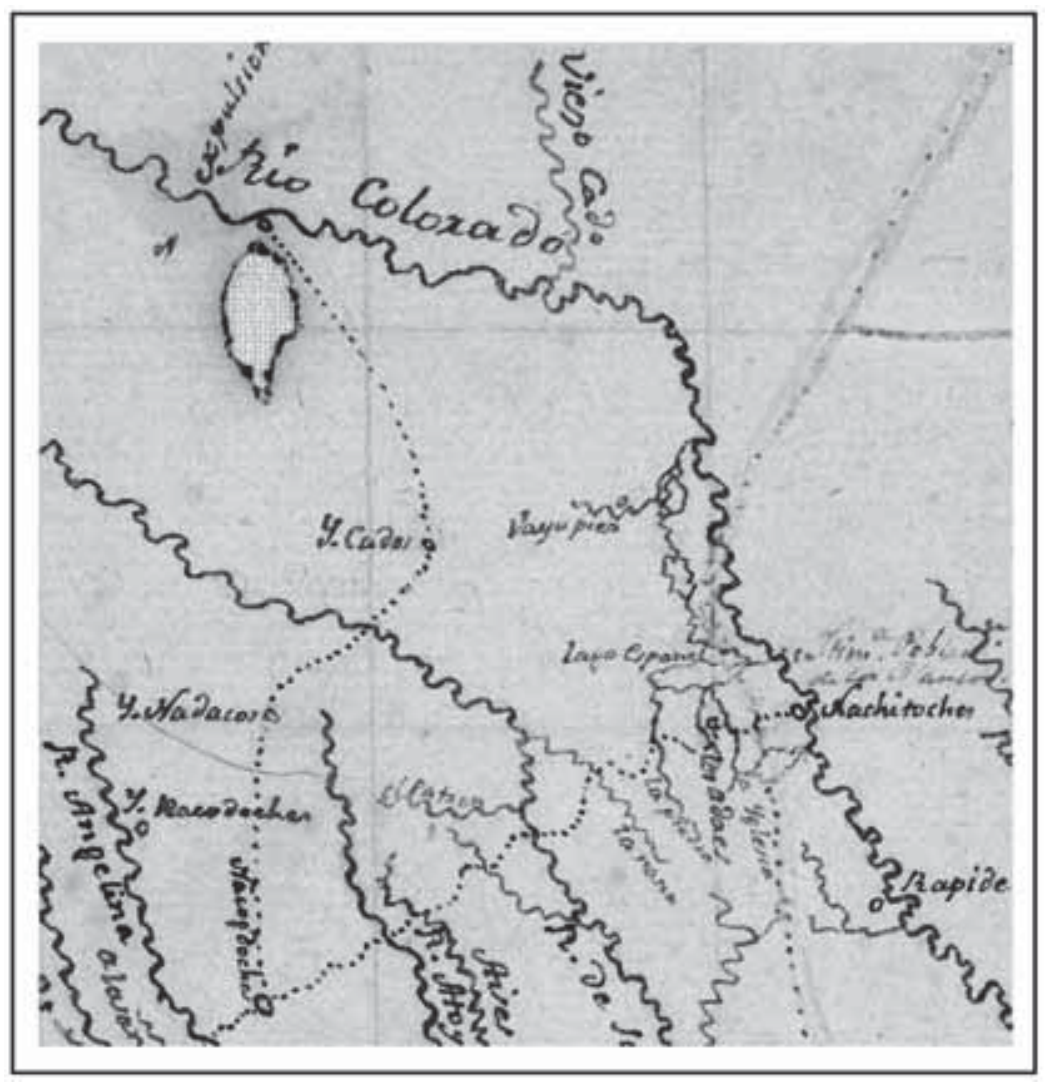

Figure 5. The Route of Spanish Troops from Nacogdoches to Spanish Bluff, Summer $1806^{41}$ 
Figure 6 is a base map of the region with selected historic and modern-day features provided for reference. A semi-transparent version of Puelles' map, resized to overlay his representations of the NadacoMt. Enterprise and Dehahuit's village locations, suggests (the scale nothwithstanding) that the route proposed above does in fact closely parallel that depicted by Puelles. When combined with the latitudinal location of the Caddo village as noted by Pichardo; the fact that the Sodo Lakes complex was not encountered by the Spanish in route to the Caddo village; and the northwesterly route taken out of the Caddo village and around the Sodo Lakes complex (probably a segment of this path was later to become known as the Natchitoches-to-Pecan Point Road) strongly suggests that the village depicted on the Puelles map lay south of modern-day Caddo Lake.

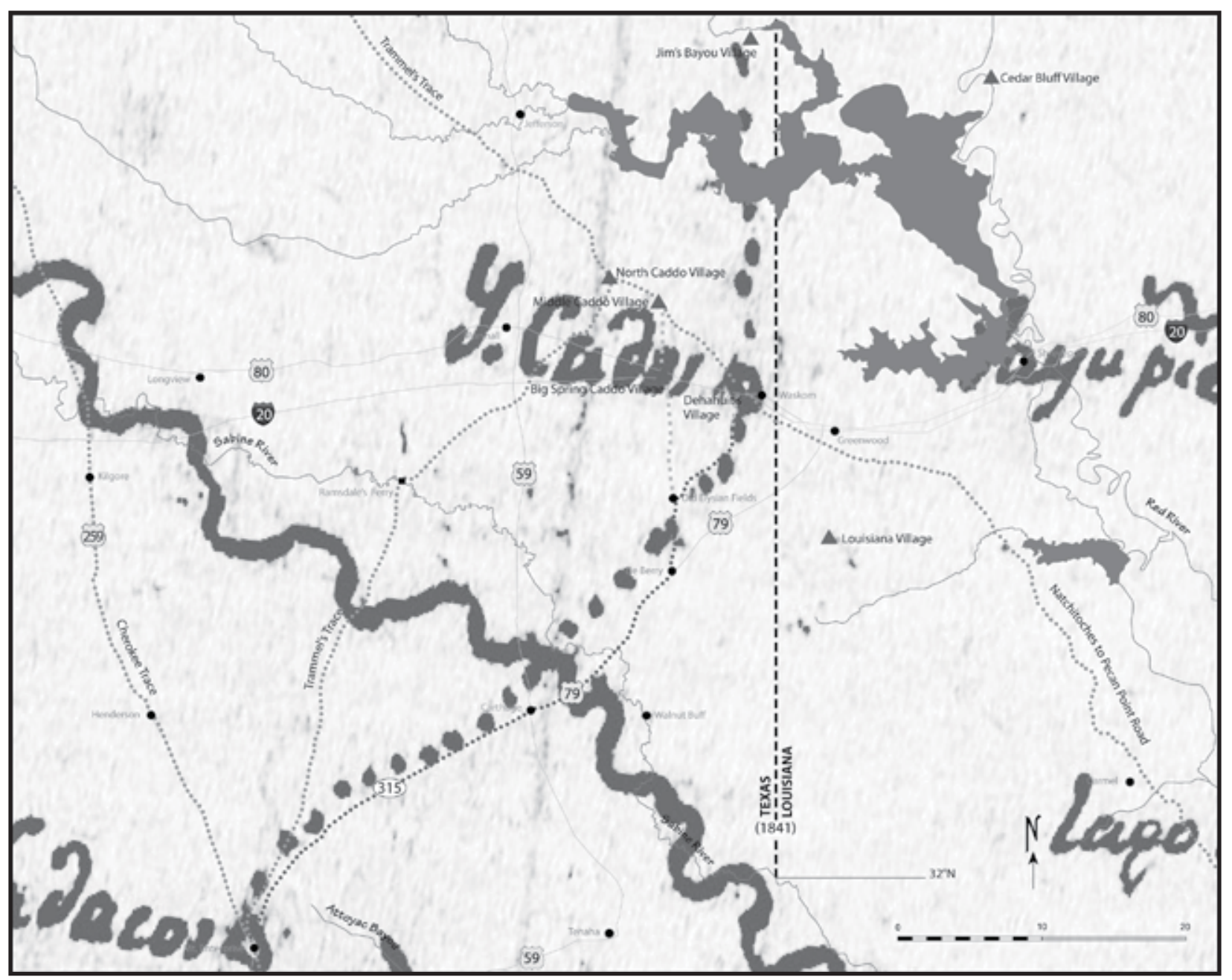

Figure 6. An Overlay of the Nadaco/Mt. Enterprise-Dehahuit Village Sites on a Modern Map of the Region South of Caddo Lake ${ }^{42}$

\section{The Caddo Village on William Darby's 1816 Map of Louisiana}

The northwest Louisiana Caddo village depicted on William Darby's 1816 map of that state is often identified as the village of Dehahuit (see Figure 3). Based on a geographical analysis of the map and the material presented in this series of articles, there is little period evidence that supports such a conclusion. Darby's Caddo settlement more likely represents a substantial, and as yet to be discovered, Caddo site. 
We begin our discussion of Darby's map with a few comments regarding what Darby actually knew about northwestern Louisiana. While we know he travelled over much of the state prior to the publication of his map, there is no evidence Darby ever personally explored the region west of the Red River and north of his 1812 traverse. As he tells us in his 1818 Emigrant's Guide to the Western and Southwestern States and Territories

The author commenced a traverse at the town of Natchitoches on Red river, and measured the several courses between the latter and Sabine. From a wish to include the then vaguely known settlement of Bayou Pierre, the traverse was extended northwest along the overflown lands [the Raft] of Red river, as high as $32^{\circ} 10^{\prime} 21^{\prime \prime} \mathrm{N}$ lat., and then curved to the Sabine. By this means the creeks, lakes, and settlements, N.W. of Natchitoches were delineated upon Darby's large map of Louisiana. ${ }^{30}$

The reader will note that Darby's travels left him some 50 miles short of the 33rd parallel (the northern border of Louisiana); or put another way, his route to the Sabine took him barely 10 miles north of the 32nd parallel. His knowledge of the physical and cultural features north of his October-November 1812 traverse, including the relative location of the Caddo village, was probably acquired second-hand from local residents, and most likely from his guide on his 1812 trip, "my hunter, a man of the name of Wallace." ${ }^{31}$ Wallace belonged to one of the area's pioneer families. His settlement on Cypress Bayou was a well-known frontier landmark in northwestern Louisiana west of the Red River.

The question is "Which Caddo village is depicted on Darby's map?" Caddo scholars tend to associate the settlement with the site on Jim's Bayou, however, situated as it is to the southwest of the Coushatta (Quachatta) village, and knowing what we now know about the location of Dehahuit's village, it would seem just as reasonable to conclude what is being portrayed is Dehahuit's settlement south of Paw Paw Bayou at the western end of Cross Lake. Based on an analysis of Darby's map, the author is inclined to believe the village depicted is likely neither, and instead is probably an as yet to be discovered Caddo settlement site near, or possibly even under, the western end of modern-day Caddo Lake. See again Figure 3 and consider the following

The stream sequence above Wallace's. While it is certainly possible that Wallace did not provide Darby with the names and relative location of all right bank streams entering the Raft above his home, it seems reasonable to assume that the larger streams, and in particular those closest to his settlement on Cypress Bayou, would have been identified. It appears that the streams shown, moving in sequence north from Wallace's, are as follows: Cypress Bayou (Wallace's settlement is located to the south of this watercourse), Cross Bayou (there is no Cross Lake depicted), and modern-day Twelvemile Bayou which drains the elongated northwest to southeast Sodo Lakes complex less the Cross Lake component. The reader will note that the lake complex on Darby's map, as is occasionally depicted on early 1800 s maps, is tilted in a slightly northwest to southeast direction. ${ }^{32}$

The configuration of the southern lake on Darby's map and the location of the village upon that lake. Granted it requires some imagination, but note the lake appendages as one moves in a counterclockwise direction from the southeast (Sodo Lake/Twelvemile Bayou) - Shifttail-Clear Lake and the distinctive elbow-like arm of Jim's Bayou. Interestingly, Darby has depicted the lake extending up Jim's Bayou beyond the Jim's Bayou village as discussed at some length in Part I of this series of articles. To the west is a much smaller (at least from its 1838 configuration) Ferry Lake with the Caddo village located to the south of Big Cypress Bayou. A modern topographic map suggests that the western end of old Ferry Lake north of Karnack could have exhibited a bulbous configuration similar to that shown on Darby's map. Across the western/southern end of the lake are, in sequence from the Caddo village, Harrison Bayou, Watson's Bayou (which is situated almost directly south of the Jim's Bayou arm of the lake, and even 
today still exhibits a semi-triangular-shaped bay where it enters Caddo Lake), ${ }^{33}$ and finally what may have been Walnut Bayou which enters Caddo Lake just east of modern-day Mooringsport.

The configuration and relative location of the large lake to the west of the Coushatta village. To those who believe Dehahuit's village was in fact located at the western end of Cross Lake, it might be tempting to suggest that the large waterbody to the west of the Coushatta village was the Ferry-Clear-Shifttail-Sodo Lakes segment of the lakes complex. However, the 1838-1839 United States surveys of the region clearly show a large cypress brake associated with Black Bayou lying generally northwest of the Coushatta village site. The configuration of the brake depicted on these survey plats is remarkably similar to that of Darby's northern lake. ${ }^{34}$

Darby's depiction of latitudinal location. As might be expected, Darby's latitudinal locations are relatively accurate across those portions of Louisiana he actually traversed. For instance, Natchitoches was located by Darby at $31^{\circ} 45^{\prime} \mathrm{N}$ (it is found at $31^{\circ} 45^{\prime} \mathrm{N}$ - he placed the settlement at its actual location). He located Gaines Ferry on the Sabine at approximately $31^{\circ} 29^{\prime} \mathrm{N}$ (it is actually found at $31^{\circ} 28^{\prime} \mathrm{N}$ - Darby placed the ferry less than one mile north of its actual location). He located Wallace's settlement at approximately $32^{\circ} 17^{\prime} \mathrm{N}$ (it is actually at $32^{\circ} 18^{\prime} \mathrm{N}$ - Darby placed the site approximately 1 mile south of its actual location). The reader will note that while Darby did not actually visit this settlement, Wallace was Darby's guide. Too, the fact Wallace lived less than 10 miles north of Darby's route through the Bayou Pierre region doubtless aided Darby in the relatively accurate placement of his homesite on the map.

Once Darby began to rely on others for the position of more distant geographic points of interest, his locations became less reliable. For instance, he located the Coushatta village at approximately $32^{\circ} 37^{\prime} \mathrm{N}$ (it is actually found at $32^{\circ} 47^{\prime} \mathrm{N}$ - Darby placed the village approximately 10 miles south of its actual location). He located the confluence of the Sulfur Fork and Red Rivers at $32^{\circ} 53^{\prime} \mathrm{N}$ (it is actually found in Arkansas at $33^{\circ} 5^{\prime} \mathrm{N}$ - Darby located the confluence some 12 miles south of its true location). Above his 1812 route to the Sabine, save for Wallace's settlement, Darby's latitudinal points appear to have been in error an average of approximately 11 miles south their actual locations. The Caddo village was located by Darby at approximately $32^{\circ} 33^{\prime} \mathrm{N}$. If we assume the site depicted was actually some 11 miles north of this point, the settlement would be located at approximately $32^{\circ} 44^{\prime} \mathrm{N}$. Modern latitudinal measurements place the Jim's Bayou site at $32^{\circ} 50^{\prime} \mathrm{N}$. Dehahuit's village is located at $32^{\circ} 29^{\prime} \mathrm{N}$. Jefferson, Texas, west of modern-day Caddo Lake, is located at $32^{\circ} 46^{\prime} \mathrm{N}$.

Darby's longitudinal location of the Caddo village. The international boundary north of the Sabine on Darby's map is found approximately 5.5 miles west of the present Texas Louisiana border ${ }^{35}$ His map places the Caddo village approximately 1.5 miles west of the modern Texas-Louisiana boundary. Considering the relative difficulty of locating longitudinal points in the early 1800 s, and based upon just mileage alone, it is certainly possible that either Dehahuit's settlement on Paw Paw Bayou (2.5 miles from the current border) or the Jim's Bayou site (2 miles from the current border) could have been the village depicted on Darby's map. However, due to the several factors discussed in this and the previous article on these two sites, it is the view of the author that neither of these settlements is likely to be the Caddo village depicted on Darby's map. More likely there is an undiscovered (and probably submerged and/or silted over) Caddo village site near the western end of modern-day Caddo Lake.

While Wallace almost surely had knowledge of a number of Caddo settlements in the region, it appears he did not provide Darby with the location of Dehahuit's village on Cross Lake which we know from the 1840 
statement of Brooks in the Grappe matter was at the time the home of the Caddo chief. Perhaps the reason for this lies in the fact that in 1812 Dehahuit had only been chief, and the Paw Paw Bayou site had only been occupied by the Caddo, for some 10-15 years. Wallace, whose family had a long history of trade with the Caddo, would probably have assigned much greater importance to the largest and most centrally located Caddo village in the area ${ }^{36}$ The village of the chief, especially if it were located on the periphery of the Caddo settlement region as it was, would have held less significance for him. Certainly Wallace would not have been the only period informant to fail to mention the village of Dehahuit. George Gray, Indian Agent during much of the 1820s, and an individual who had first-hand knowledge of Dehahuit's settlement, never made a specific reference to either Dehahuit or his village, and at most made only two passing references to Caddo settlements south of the Sodo Lakes complex. ${ }^{37}$

It is not possible to say with certainty whether Darby's Caddo village is the Jim's Bayou settlement, as many believe, or an as yet to be discovered Caddo site. What does seem probable is that the Caddo settlement depicted on Darby's map is not the village of Dehahuit.

\section{Summary and Conclusions}

The case for the village of the great caddi Dehahuit lying south of the Sodo Lakes complex on Paw Paw Bayou as presented by the author in this and a previous article in this journal is based on a geographical analysis of a variety of period documents. It cannot be said with certainty that the location of Dehahuit's village has been definitively established, however, the author believes that, above all other known period Caddo sites in the region, the settlement on Paw Paw Bayou most closely matches the archival record as being the home of this historic figure. While one could conceivably argue that another of the south-of-the-lakes villages may have been the home of Dehahuit, it is difficult to see how, based on the historical record, Caddo scholars can continue to claim that this individual lived on Jim's Bayou and that this site was the location of the last Caddo village in the traditional northwest Louisiana/East Texas Caddo homeland. ${ }^{38}$

\section{Endnotes}

1. Tiller, Jim. A Case for Dehahuit's Village, Part I. Caddo Archeology Journal. Vol. 20, 2010 (see URL, http:// digital.library.shsu.edu/u?/p15061 coll3,3). pp. 1-30.

2. Brooks, Jehiel. The Answer of Jehiel Brooks to the Memorial of Samuel Norris, January 30, 1840. Box 1, Folder 12, Item 8, The Brooks-Queen Family Collection. The American Catholic History Research Center and University Archives. The Catholic University of America. Washington, D.C. (see URL, www.aladin.wrlc.org/gsdl/collect/ brooks/brooks.shtml).

3. Sibley, John. "Historical Sketches of the Several Indian Tribes in Louisiana, South of the Arkansas River, and Between the Mississippi and River Grande." American State Papers. Indian Affairs. Vol. I. p. 721. In Discoveries made in exploring the Missouri, Red River, and Washita, by Captains Lewis and Clark, Doctor Sibley, and William Dunbar, Esq. [microform] with a statistical account of the countries adjacent with an appendix by Mr. Dunbar. Early American Imprints, Series 2, No 10326. p. 66, "Bayou river (Stony creek)" appears as "Bayau Pierre (Stony Creek)."

4. Castañeda, Carlos E. (James P. Gibbons, editor). Our Catholic Heritage in Texas, 1519-1936.Vol. V, The Mission Era: The End of the Spanish Regime, 1780-1810. Austin, TX: von-Boeckmann-Jones Company, 1942. p. 405.

5. Flores, Dan (editor). Jefferson and Southwestern Exploration: The Freeman \& Custis Accounts of the Red River Expedition of 1806. Norman, OK: University of Oklahoma Press, 1984. p. 145. 


\section{Endnotes (cont.)}

6. Flores, Dan (editor). Jefferson and Southwestern Exploration: The Freeman \& Custis Accounts of the Red River Expedition of 1806. Norman, OK: University of Oklahoma Press, 1984. p. 168.

7. Glass, Anthony. (Dan L. Flores, editor). Journal of an Indian Trader: Anthony Glass and the Texas Trading Frontier, 1790-1810. Texas A\&M Southwestern Studies, No. 4. College Station, TX: Texas A\&M University Press, 1985. p. 39.

8. Sibley, John. "Historical Sketches of the Several Indian Tribes in Louisiana, South of the Arkansas River, and Between the Mississippi and River Grande." American State Papers. Indian Affairs. Vol. I. p. 721.

9. 27th Cong., 2nd sess. House Report 1035. p. 28. The reader will remember that Cos Lake is an old name for Cass or modern-day Cross Lake.

10. Tiller, Jim. A Case for Dehahuit's Village, Part I. Caddo Archeology Journal. Vol. 20, March 2010 (see URL, http://digital.library.shsu.edu/u?/p15061coll3,3). pp. 2-4.

11. Parsons, Mark L., James E. Bruseth, Jaques Bagur, S. Eileen Goldborer and Claude McCrocklin. Finding Sha'chahdinnih (Timber Hill): The Last Village of the Kadohadacho in the Caddo Homeland. Archeological Reports Series, No. 3. Austin, TX: Texas Historical Commission, 2002. pp. 1-15. It appears that the material in this work is based on comments of a number of earlier writers. See Flores, Dan (editor). Jefferson and Southwestern Exploration: The Freeman \& Custis Accounts of the Red River Expedition of 1806. Norman, OK: University of Oklahoma Press, 1984. pp. 161-162, footnote 4 for a summary statement of sources.

12. Flores, Dan (editor). Jefferson and Southwestern Exploration: The Freeman \& Custis Accounts of the Red River Expedition of 1806. Norman, OK: University of Oklahoma Press, 1984. p. 143 (note 32).

13. Flores, Dan (editor). Jefferson and Southwestern Exploration: The Freeman \& Custis Accounts of the Red River Expedition of 1806. Norman, OK: University of Oklahoma Press, 1984. p. 146.

14. Flores, Dan (editor). Jefferson and Southwestern Exploration: The Freeman \& Custis Accounts of the Red River Expedition of 1806. Norman, OK: University of Oklahoma Press, 1984. p. 146.

15. Flores, Dan (editor). Jefferson and Southwestern Exploration: The Freeman \& Custis Accounts of the Red River Expedition of 1806. Norman, OK: University of Oklahoma Press, 1984. pp. 160-161.

16. Sibley, John. Letter to William Eustis, Secretary of War. November 28, 1812. National Archives and Records Administration. Letters Received by the Secretary of War, main series, 1801-1870. Record Group 107, M221, Reel 57. Material courtesy the University of Southern Mississippi. Hattiesburg, MS. See also Bagur, Jacques. $A$ History of Navigation on Cypress Bayou and the Lakes. Denton, TX: University of North Texas Press, 2001. pp. 11-13; Garrett, Julia Kathryn. "Dr. John Sibley and the Louisiana-Texas Frontier, 1803-1814." Southwestern Historical Quarterly. Vol. 49, No. 3 (January 1946). pp. 417-418.

17. A Map of the State of Louisiana with Part Of The Mississippi Territory, from Actual Survey By Wm. Darby. 1816. William Darby, surveyor. Philadelphia, PA: John Melish. The David Rumsey Map Collection (see URL, www. davidrumsey.com); Austin, Stephen F. Mapa Original de Texas. Scale, none given. Note on map: "Presented to his Excellency the President, by the author in 1829." Map Number 0917, Map Collection. Archives and Information Services Division. Texas State Library and Archives Commission. Austin, Texas.

18. Flores, Dan (editor). Jefferson and Southwestern Exploration: The Freeman \& Custis Accounts of the Red River Expedition of 1806. Norman, OK: University of Oklahoma Press, 1984. p. 146.

19. Flores, Dan (editor). Jefferson and Southwestern Exploration: The Freeman \& Custis Accounts of the Red River Expedition of 1806. Norman, OK: University of Oklahoma Press, 1984. pp. 147-148. 


\section{Endnotes (cont.)}

20. Flores, Dan (editor). Jefferson and Southwestern Exploration: The Freeman \& Custis Accounts of the Red River Expedition of 1806. Norman, OK: University of Oklahoma Press, 1984. pp. 145-146.

21. While there are hints in the journals themselves, see references in Flores' Jefferson and Southwestern Exploration to a "very rapid" current (p. 134), "against a current, running at the rapid rate of three miles an hour" (p. 136), and "a rise in the water, which we observed was taking place" (p. 140), the comment about swimming the horses of the Caddo party across the Red River at a time (late June-early July) when it would normally have been possible for a person to have walked across the river in a number of places (p. 161), perhaps the most compelling information regarding the probable level of the Sodo Lakes complex in the summer of 1806 can be found in Appendix Three ("Meteorological observations made on Red River, 1806" (pp. 336- 339)). An analysis of these tables clearly shows at least three cyclonic frontal passages (typically characterized by periods of widespread and extended precipitation) were experienced in the area between May 2 and June 15. Of the 30 days of record in May, fully 15 experienced rainfall; seven of the first 15 days in June experienced rainfall. Notes accompanying the tables make use of such adjectives as "great rain" (May 12), "violent thunderstorm" (May 13), "excessive rain" (May 15), "much rain" (May 17), and "heavy shower" (May 23). Many of the rainfall periods are associated with thunder and lightning, and also include a number of days with gentle showers in the morning, rains beginning at night and stretching through the next day, and extended period of cloudy weather - all characteristics of the presence of cyclonic fronts. Such fronts, which typically impact broad geographic areas, almost surely brought sustained and widespread rainfall throughout the watershed of the Red River in the late spring of 1806. Based on materials found in the Freeman and Custis journals, it is very likely that area streams and lakes, following upon what were typically the wet spring months, would have been unusually high for early summer.

Interestingly, a 1987 paper by Quinn and others in the Journal of Geophysical Research suggests that a moderate El Niño was experienced along coastal Peru in 1806. Peruvian El Niño incidents are typically associated with periods of increased rainfall across the southern United States (see Quinn, W. H., V. T. Neal, and S. E. Antunez de Mayolo. El Niño Occurrences Over the Past Four and a Half Centuries. Journal of Geophysical Research. Vol. 92 (C13), 1987. pp. 14449-14461).

22. Flores, Dan (editor). Jefferson and Southwestern Exploration: The Freeman \& Custis Accounts of the River Expedition of 1806. Norman, OK: University of Oklahoma Press, 1984. pp. 160-161; Parsons, Mark L., James E. Bruseth, Jaques Bagur, S. Eileen Goldborer and Claude McCrocklin. Finding Sha'chahdinnih (Timber Hill): The Last Village of the Kadohadacho in the Caddo Homeland. Archeological Reports Series, No. 3. Austin, TX: Texas Historical Commission, 2002. p. 15.

23. Flores, Dan (editor). Jefferson and Southwestern Exploration: The Freeman \& Custis Accounts of the Red River Expedition of 1806. Norman, OK: University of Oklahoma Press, 1984. p. 165.

24. See for instance Mapa Geographica de la Provincia Tehas. 1822. Stephen F. Austin. Document di_02881, Stephen Austin Map Collection. Dolph Briscoe Center for American History, The University of Texas at Austin. Austin, Texas; Bradford, Thomas G. Texas. An Illustrated Atlas, Geographical, Statistical, and Historical, of the United States and Adjacent Countries. Scale, 1.75 inches is 80 miles. 1838. Map Number 0033, Map Collection. Archives and Information Services Division. Texas State Library and Archives Commission. Austin, Texas

25. 1834. David H. Burr, draftsman. New York, NY: J.H. Colton and Company. Document 79292, Digital Collection. Professional Services Program Area, Surveying Division. Texas General Land Office. Austin, Texas.

26. Mapa Geographica de las Provincias Septentrionales de esta Nueva Espana. 1807? Father José Maria Puelles. Document di_04655, Texas Cartography Collection. Dolph Briscoe Center for American History, The University of Texas at Austin. Austin, Texas.

27. Jackson, Jack. Shooting the Sun: Cartographic Results of Military Activities in Texas, 1689-1829. Vol. 2. The Book Club of Texas, 1998. p. 316. 


\section{Endnotes (cont.)}

28. Pichardo, Father José Antonio (Charles Wilson Hackett, editor). Pichardo's Treatise on the Limits of Louisiana and Texas: An Argumentative Historical Treatise with Reference to the Verification of the True Limits of the Provinces of Louisiana and Texas: Written by Father José Antonio Pichardo, of the Congregation of the Oratory of San Felipe Neri, to Disprove the Claim of the United States That Texas Was Included in the Louisiana Purchase of 1803. Vol. 4. Austin, TX: The University of Texas Press, 1946. p. 421.

29. Jackson, Jack. Shooting the Sun: Cartographic Results of Military Activities in Texas, 1689-1829. Vol. 2. The Book Club of Texas, 1998. p. 329.

30. Darby, William. Emigrant's Guide to the Western and Southwestern States and Territories. New York, NY: Kirk and Mercein, 1818. pp. 84-85.

31. Darby, William. Letter to the Editor. Daily National Intelligencer. May 13, 1836.

32. Texas General Land Office. Digital Collection. Tanner, Henry S. Map of Texas with Parts of the Adjoining States. Scale, 1 inch is 25 miles. Philadelphia, PA: Henry S. Tanner. 1839. GLO Map Image 88995. Archives and Records Division, Austin, Texas; Texas General Land Office. State Collection. Groves, H. Republic of Texas. Scale, 1 inch is 25 miles. 1837. GLO Image 476. Archives and Records Division, Austin, Texas.

33. Silting has filled in much of today's Buzzard Bay at the point where Watson's Bayou enters Caddo Lake. The May 1838 American survey plat of T19N, R16W much more clearly delineates the distinctive triangular shape seen on Darby's map. See United States Department of the Interior, Bureau of Land Management. Louisiana, North and West District. Survey Plat Map for T19N, R16W (1838). Available from the Bureau of Land Management, Springfield, Virginia. Paper copies (18" X 24") may be acquired from the Bureau of Land Management in Springfield, Virginia. Also available online at http://www.glorecords.blm.gov/ (see Search Surveys).

34. United States Department of the Interior, Bureau of Land Management. Louisiana, North and West District. Survey Plat Maps and Field Notes for T22N, R15W (1839), T22N, R16W (1839) and 23N, 16W (1839). Available from the Bureau of Land Management, Springfield, Virginia. Paper copies (18" X 24") may be acquired from the Bureau of Land Management in Springfield, Virginia. Also available online at http:// www.glorecords.blm.gov/ (see Search Surveys).

35. Tiller, Jim. Before the Line. Vol. I, An Annotated Atlas of International Boundaries and Republic of Texas Administrative Units. Huntsville, TX: The START Group, 2010 (see URL, http://digital.library.shsu.edu/u?/ p15061coll3,0). pp. 7-16.

36. Brooks, Jehiel. The Answer of Jehiel Brooks to the Memorial of Samuel Norris, January 30, 1840. Box 1, Folder 12, Item 8, The Brooks-Queen Family Collection. The American Catholic History Research Center and University Archives. The Catholic University of America. Washington, D.C. (see URL, www.aladin.wrlc. org/gsdl/collect/brooks/brooks.shtml); Flores, Dan (editor). Jefferson and Southwestern Exploration: The Freeman \& Custis Accounts of the Red River Expedition of 1806. Norman, OK: University of Oklahoma Press, 1984. See footnote 3, pp. 160-161; Perttula, Timothy K. The Caddo Nation. Austin, TX: The University of Texas Press, 1992. pp. 40-41; 27th Cong. 2nd sess. House Report 1035. pp. 24-25, 33, 86.

37. National Archives and Records Administration. Letters Received by the Office of Indian Affairs, 1824-1881, Red River Agency. M234, Roll 727. Letter from George Gray, Agent to Thomas McKinney, Superintendent of Indian Affairs, October 1, 1824; letter from George Gray, Agent to James Barbour, Secretary of War, December 4, 1825. See also Tiller, Jim. Before the Line. Vol. II, Letters from the Red River, 1809-1842. Huntsville, TX: The START Group, 2011 (see URL, http://digital.library.shsu.edu/u?/p15061coll3,8). Items 301, 323. 


\section{Endnotes (cont.)}

38. Parsons, Mark L., James E. Bruseth, Jaques Bagur, S. Eileen Goldborer and Claude McCrocklin. Finding Sha'chahdinnih (Timber Hill): The Last Village of the Kadohadacho in the Caddo Homeland. Archeological Reports Series, No. 3. Austin, TX: Texas Historical Commission, 2002. pp. 1-15. See Tiller, Jim. Was Timber Hill the Last Caddo Village in the Caddo Homeland? Caddo Archeology Journal. Vol. 18, 2008 (see URL, http://digital.library.shsu.edu/u?/p15061coll3,2). pp. 11-21 for a rebuttal of the case for the Jim's Bayou site (erroneously designated in the article as Timber Hill by the author) being the last Caddo village in the northwestern Louisiana-East Texas region.

39. Figure 2. Items 1-7 correspond to the first seven items listed under the section entitled "Distance and Direction." Except for item 2, each item was developed as follows: (1) the top (black) bar represents the distance referenced by the individual/company indicated. For instance, in item 1 Brooks estimated the distance from Natchitoches to Dehahuit's village to be 90 miles; (2) the dark gray bar (Dehahuit's Village) depicts the actual distance (either via straight line or by a specified road) from the initial point referenced (Natchitoches) to Dehahuit's village. When determining straight line mileage, distances were calculated without regard to physical features (lakes, swamps, etc.). The presence of such features would, of course, add mileage to the calculated total. In the case of item 1, Dehahuit's village is located 87 miles north of Natchitoches via the Natchitoches-to-Pecan Point Road as depicted on 1830s-era United States survey plat maps; (3) the light gray bar represents Jim's Bayou village. In item 1, Jim's Bayou is located 110 miles from Natchitoches (87 miles to Dehahuit's village as measured along the Natchitoches-to-Pecan Point Road plus 24 miles as measured on a straight line from Dehahuit's village to the Jim's Bayou village).

The mileages shown in item 2 were calculated as follows: (1) Sibley estimated that the Yatasi tribe was centered on modern-day Buffalo Bayou, 50 miles above Natchitoches. The distance as calculated along the old Natchitoches-to-Pecan Point Road was determined to actually be 41 miles. The distance from the old Natchitoches-to-Pecan Point Road-Buffalo Bayou intersection to Dehahuit's village, as measured on a straight line, was determined to be 37 miles, the total (78 miles) being very close to the double the "halfway" distance suggested by Sibley. To compare, the Jim's Bayou site, as measured on a straight line, was calculated to be some 59 miles above the intersection of the old Natchitoches-to-Pecan Point Road and Buffalo Bayou, or a total of 100 miles above Natchitoches.

40. Figure 3. Source: A Map of the State of Louisiana with Part Of The Mississippi Territory, from Actual Survey By Wm. Darby. 1816. William Darby, surveyor. Philadelphia, PA: John Melish. The David Rumsey Map Collection (see URL, www. davidrumsey.com).

41. Figure 5. Source: adapted from Mapa Geographica de las Provincias Septentrionales de esta Nueva Espana. 1807? Father José Maria Puelles. Document di_04655, Texas Cartography Collection. Dolph Briscoe Center for American History, The University of Texas at Austin. Austin, Texas.

42. Figure 6. Source: adapted from Mapa Geographica de las Provincias Septentrionales de esta Nueva Espana. 1807? Father José Maria Puelles. Document di_04655, Texas Cartography Collection. Dolph Briscoe Center for American History, The University of Texas at Austin. Austin, Texas. 